\title{
PEMBENTUKAN DAN PELATIHAN FORUM PEDULI KIA DI KELURAHAN KURAO PAGANG KOTA PADANG
}

\author{
Desi Wildayani $^{1}$, Devi Syarief ${ }^{2}$, Nur Fadjri Nilakesuma ${ }^{3}$, Novria Hesti ${ }^{4}$, \\ Amelia Indah Pratiwi ${ }^{5}$, Putri Hasanah ${ }^{6}$, Ramadhany Hafsah Qonita ${ }^{7}$, \\ Sena Pebrina ${ }^{8}$ \\ ${ }^{1-8)}$ Prodi Kebidanan Program Sarjana dan Pendidikan Profesi Bidan Program Profesi \\ STIKes MERCUBAKTIJAYA Padang \\ email : desiwildayani@mercubaktijaya.ac.id
}

\begin{abstract}
Abstrak
Kehamilan merupakan peristiwa yang sangat membahagiakan bagi ibu hamil yang merencanakan dan menantikan kehamilannya. Kehamilan juga dapat menimbulkan kecemasan dan kekhawatiran apabila mengalami komplikasi yang mengancam jiwa. Salah satu upaya pemerintah dalam rangka menurunkan angka kematian ibu adalah mencanangkan Program Perencanaan Persalinan dan Pencegahan Komplikasi (P4K). Program ini dapat memantau ibu hamil oleh seluruh komponen masyarakat, baik suami, keluarga dan bidan secara cepat dan tepat. Indikator P4K adalah dengan pemasangan stiker $\mathrm{P} 4 \mathrm{~K}$ yang terdiri dari nama ibu hamil, taksiran persalinan, penolong persalinan, tempat persalinan, transportasi dan calon donor darah. Strategi P4K dengan stiker ini merupakan suatu kegiatan yang di fasilitasi oleh Bidan di desa/kelurahan dalam rangka membuat suami, keluarga dan masyarakat ikut berperan aktif dalam merencanakan persalinan yang aman dan persiapan menghadapi komplikasi bagi ibu hamil, termasuk perencanaan penggunaan KB pasca persalinan dengan menggunakan stiker sebagai media notifikasi sasaran dalam rangka meningkatkan cakupan dan mutu pelayanan kesehatan bagi ibu dan bayi baru lahir. Salah satu kelurahan di wilayah kerja Puskesmas Nanggalo Kota Padang adalah Kelurahan Kurao Pagang, dengan cakupan pelayanan kesehatan ibu hamil baru mencapai 67,39\%. Salah Satu upaya untuk meningkatkan pencapaian pelayanan kesehatan ibu hamil di Kelurahan Kurao Pagang, dengan kegiatan pembentukan forum peduli KIA, kemudian forum dan kader dilatih tentang stiker P4K dan dilakukan aksi pemasangan stiker P4K tersebut di rumah ibu hamil.
\end{abstract}

Kata Kunci : Pembentukan forum peduli KIA, Stiker P4K

\begin{abstract}
Pregnancy is a very happy event for pregnant women who are planning and looking forward to their pregnancy. Pregnancy can also cause anxiety and worry if you have life-threatening complications. One of the government's efforts to reduce maternal mortality is to launch the Maternity Planning and Complications Prevention Program (P4K). This program can monitor pregnant women by all components of society, including husbands, families and midwives quickly and accurately. The P4K indicator is the installation of a $\mathrm{P} 4 \mathrm{~K}$ sticker consisting of names of pregnant women, estimated deliveries, birth attendants, places of delivery, transportation and potential blood donors. The P4K strategy with this sticker is an activity facilitated by midwives in villages / kelurahan in order to make husbands, families and communities take an active role in planning safe delivery and preparation for complications for pregnant women, including planning for postpartum family planning using stickers. As a target notification media in order to increase the coverage and quality of health services for mothers and newborns. One of the sub-district in the working area of Nanggalo Health Care Padang City is Kurao Pagang Sub-District, with the coverage of health services for pregnant women only reaching $67.39 \%$. One of the efforts to improve the achievement of health services for pregnant women in Kurao Pagang Village is by establishing a Mother and Child Health $(\mathrm{MCH})$ care forum, then training forums and cadres on P4K stickers and installing P4K stickers at pregnant women's homes.
\end{abstract}

Keywords : Formation of MCH care forum, Stickers P4K 


\section{PENDAHULUAN}

Kehamilan merupakan pertumbuhan dan perkembangan janin intrauterin mulai konsepsi dan berakhir sampai permulaan persalinan. Hal ini merupakan peristiwa yang sangat membahagiakan bahi ibu hamil yang merencanakan dan menantikan kehamilannya. Kehamilan juga dapat menimbulkan kecemasan dan kekhawatiran apabila mengalami komplikasi yang mengancam jiwa (Yulianti, 2018).

Keberhasilan upaya kesehatan ibu, di antaranya dapat dilihat dari indikator Angka Kematian Ibu (AKI). AKI adalah jumlah kematian ibu selama masa kehamilan, persalinan dan nifas yang disebabkan oleh kehamilan, persalinan, dan nifas atau pengelolaannya tetapi bukan karena sebabsebab lain seperti kecelakaan atau terjatuh di setiap 100.000 kelahiran hidup. Indikator ini dipengaruhi status kesehatan secara (umum, pendidikan dan pelayanan selama kehamilan dan melahirkan. Sensitifitas AKI terhadap perbaikan pelayanan kesehatan menjadikannya indikator keberhasilan pembangunan sector kesehatan, baik dari sisi aksesibilitas maupun kualitas (Kementerian Kesehatan Republik Indonesia, 2018).

Angka Kematian Ibu juga merupakan salah satu target yang ditentukan dalam Sustainable Development Goals (SDGs) mewujudkan kesehatan yang baik dengan menurunkan AKI, dimana target yang akan dicapai di tahun 2030 sebesar 70/100.000 kelahiran hidup. Data terakhir dari Kementrian Kesehatan AKI 2016 tercatat 305 per 100.000 kelahiran hidup (Kementerian Kesehatan Republik Indonesia, 2018). Penyebab langsung kematian ibu adalah kurang lebih $90 \%$ pada saat persalinan dengan komplikasi yaitu hipertensi $(28,8 \%)$, obesitas $(32,9 \%)$ dan anemia $(37,1 \%)$, sedangkan sebab tidak langsungnya antara lain disebabkan oleh sosial ekonomi, pendidikan, peranan wanita, sosial budaya dan transformasi yang digambarkan dengan istilah " Tiga Terlambat" dan "Empat Terlalu" (Prasetyawati, 2012).

Angka kematian Ibu pada tahun 2017 di Kota Padang ditemukan sebanyak 16 kasus, jumlah ini mengalami penurunan jika dibanding tahun 2016 (20 orang). Upaya percepatan penurunan AKI dapat dilakukan dengan menjamin agar setiap ibu mampu mengakses pelayanan kesehatan ibu yang berkualitas, seperti pelayanan kesehatan ibu hamil, pertolongan persalinan oleh tenaga kesehatan terlatih di fasillitas pelayanan kesehatan, perawatan pasca persalinan bagi ibu dan bayi, perawatan khusus dan jika terjadi komplikasi, kemudahan mendapatkan cuti hamil dan melahirkan, dan pelayanan keluarga berencana.

Untuk menanggulangi masalah tersebut telah dilakukan upaya penurunan AKI. Pada tahun 2000 Departemen Kesehatan telah mencanangkan Strategi Making Pregnancy Safer (MPS) yang merupakan strategi terfokus dalam penyediaan dan pemantapan pelayanan kesehatan dengan 3 (tiga) pesan kunci MPS: (1) Setiap persalinan ditolong oleh tenaga kesehatan terlatih, (2) Setiap komplikasi obstetri dan neonatal mendapat pelayanan yang adekuat, dan (3) Setiap wanita usia subur mempunyai akses terhadap pencegahan kehamilan yang tidak diinginkan dan penanganan komplikasi keguguran. Upaya penurunan AKI tersebut dilaksanakan melalui empat strategi, yaitu: (1) Peningkatan kualitas dan akses pelayanan kesehatan ibu dan bayi, (2) Kerjasama lintas program, lintas sektor terkait dan masyarakat termasuk swasta, (3) Pemberdayaan perempuan, keluarga, dan pemberdayaan masyarakat, dan (4) Meningkatkan surveilence, monitoring-evaluasi KIA dan pembiayaan (Sarli \& Ifayanti, 2018).

Kasus kehamilan berisiko banyak ditemukan di masyarakat tetapi tenaga kesehatan tidak bisa menemukannya satu persatu, karena itu peran serta masyarakat (kader) sangat dibutuhkan dalam mendeteksi ibu hamil risiko tinggi (Muslihatun, 2009). Seorang kader tidak hanya melakukan kegiatan pada saat pelaksanaan posyandu, melainkan harus selalu tanggap dan peduli dengan masalah kesehatan ibu dan anak di lingkungannya. Kader diharapkan dapat jeli menemukan masalah dan melakukan penilaian terhadap masalah tersebut. Yaitu menemukan masalah yang paling mendesak untuk ditangani dan menentukan kegiatan untuk menangani masalah tersebut (Tengah, 2009).

Strategi $\mathrm{P} 4 \mathrm{~K}$ dengan stiker ini merupakan suatu kegiatan yang di fasilitasi oleh Bidan di desa/kelurahan dalam rangka membuat suami, keluarga dan masyarakat ikut berperan aktif dalam merencanakan persalinan yang aman dan persiapan menghadapi komplikasi bagi ibu hamil, termasuk perencanaan penggunaan KB pasca persalinan dengan menggunakan stiker sebagai media notifikasi sasaran dalam rangka meningkatkan cakupan dan mutu pelayanan kesehatan bagi ibu dan bayi baru lahir. Tujuan P4K adalah untuk meningkatkan cakupan dan mutu pelayanan 
kesehatan bagi ibu hamil dan bayi baru lahir. Pelaksanaan strategi ini dilakukan pemeriksaan kehamilan oleh bidan atau tenaga kesehatan sebagai upaya untuk meningkatkan pengetahuan ibu hamil, suami dan keluarga (Yulianti, 2018).

Pencegahan komplikasi (P4K) merupakan bagian dari pelayanan antenatal yang diberikan pada ibu hamil. Pelayanan ini juga termasuk dalam pencapaian program pelayanan kesehatan ibu hamil. Target pencapaian program pelayanan kesehatan ibu hamil di puskesmas Nanggalo mencapai target $98,7 \%$. Hal ini masih rendah jika dibandingkan dengan target nasional yaitu $100 \%$ (Dinas Kesehatan Kota Padang, 2017). Puskesmas Nanggalo terdiri dari 3 kelurahan, yaitu kelurahan Kurao Pagang, Gurun Laweh dan Surau Gadang. Cakupan pelayanan kesehatan ibu hamil di kelurahan Kurao Pagang batu mencapai 67,39\%. Untuk meningkatkan pencapaian pelayanan kesehatan ibu hamil di Kelurahan Kuarao Pagang, dengan kegiatan pembentukan forum peduli KIA. Salah satu program kerja dari forum ini adalah Pencegahan komplikasi (P4K).

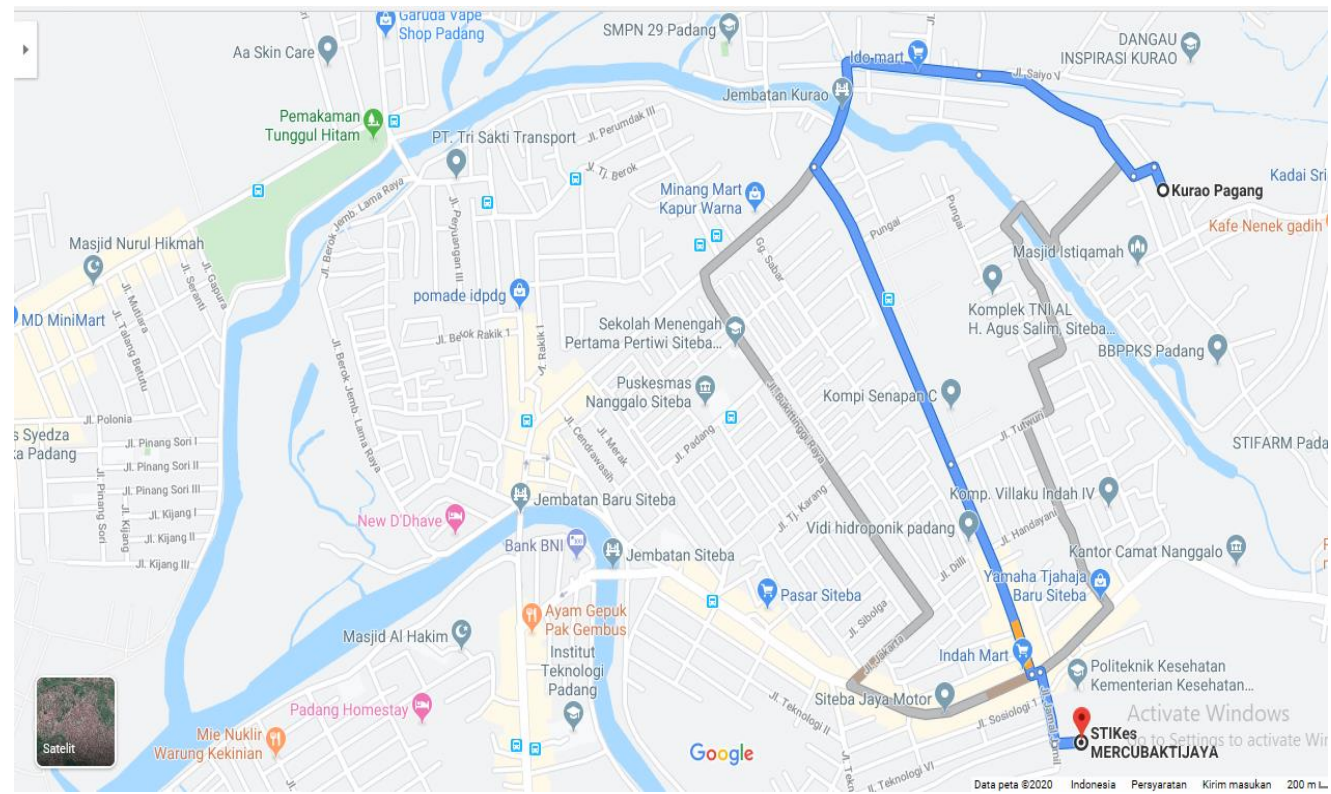

Gambar 1. Peta lokasi pengabdian kepada masyarakat di Kelurahan Kurao Pagang

\section{METODE}

\subsection{Tahap Persiapan}

Melakukan koordinasi dengan Kelurahan Kurao Pagang dan Bidan Pembina Wilayah untuk membahas kegiatan yang akan dilakukan. Kedatangan tim pengabdi disambut baik oleh pihak Kelurahan. Rangkaian kegiatan pengabdian masyarakat ini, direncanakan akan disepakati pada saat setelah pertemuan dan pembentukan forum tersebut, kegiatannya antara lain, pelatihan kader tentang stiker P4K dan tanda bahaya kehamilan, persalinan dan nifas. Di samping itu juga disiapkan instrumen pengabdian yang akan dilakukan seperti berita acara pelaksanaan pengabdian, daftar hadir peserta, doorprize, bahan untuk pelatihan.

\subsection{Tahap Pelaksanaan}

Sebelum melaksanakan kegitan pengabdian masyakarat, ibu kader posyandu yang hadir diminta dulu untuk mengisi kuesoioner pretest yang diberikan untuk mengukur sejauh mana pemahaman kader dan kelompok masyakarat peduli KIA tentang stiker P4K dan tanda bahaya pada kehamilan, persalinan, serta nifas.

\subsection{Evaluasi}

\subsubsection{Struktur}

a) Kegiatan pembentukan forum / kelompok masyarakat Peduli KIA

Jumlah undangan yang hadir pada saat kegiatan pembentukan forum tersebut adalah 34 orang dari 62 orang. Hal ini disebabkan oleh sebagian dari undangan ada yang bekerja sehingga tidak dapat menghadiri kegiatan tersebut. Setting tempat sudah sesuai dengan 
rencana yang dibuat dan perlengkapan yang dilakukan untuk pengabdian sudah tersedia dan sudah digunakan sebagaimana mestinya. Pembagian peran antar anggota tim terorganisasi dengan baik.

b) Kegiatan pelatihan kader dan kelompok masyarakat Peduli KIA tentang Stiker P4K dan Tanda Bahaya pada Kehamilan, Persalinan, serta Nifas

Jumlah undangan yang hadir pada saat kegiatan pelatihan kader tersebut adalah 15 orang dari 38 orang. Hal ini disebabkan oleh sebagian dari undangan ada yang bekerja sehingga tidak dapat menghadiri kegiatan tersebut. Setting tempat sudah sesuai dengan rencana yang dibuat dan perlengkapan yang dilakukan untuk pengabdian sudah tersedia dan sudah digunakan sebagaimana mestinya. Pembagian peran antar anggota tim terorganisasi dengan baik.

\subsubsection{Proses}

a) Kegiatan pembentukan forum / kelompok masyarakat Peduli KIA

Pelaksanaan kegiatan pukul $14.00-15.15$ WIB. Sesuai dengan jadwal yang telah direncanakan.

b) Kegiatan pelatihan kader dan kelompok masyarakat Peduli KIA tentang Stiker P4K dan Tanda Bahaya pada Kehamilan, Persalinan, serta Nifas

Pelaksanaan kegiatan pukul $09.00-11.30$ WIB. Sesuai dengan jadwal yang telah direncanakan.

\subsubsection{Hasil}

a) Kegiatan pembentukan forum / kelompok masyarakat Peduli KIA

Terbentuknya kelompok masyarakat Peduli Kesehatan Ibu dan Anak (KIA), yang diketuai oleh ibu Yustina, SE dan dari pihak institusi diketuai oleh ibu Desi Wildayani, Bd., M.Keb, bentuk kegiatannya adalah Pelatihan tentang Program Perencanaan Persalinan dan Pencegahan Komplikasi (P4K) dengan Stiker serta Aksi pemasangan Stiker P4K bersama oleh Forum Peduli KIA, pengabdi, ibu hamil dan bidan Pembina wilayah.

b) Surat Keputusan (SK) untuk kelompok masyarakat tersebut dikeluarkan dan disahkan oleh Lurah Kelurahan Kurao Pagang, Bapak Masril, S.Pd.

c) Kegiatan pelatihan kader dan kelompok masyarakat Peduli KIA tentang Stiker P4K dan Tanda Bahaya pada Kehamilan, Persalinan, serta Nifas

d) Terdapat peningkatan pengetahuan kader tentang tanda bahaya pada kehamilan, persalinan dan nifas serta pemahaman tentang stiker P4K setelah diberikan pelatihan. Hal ini dibuktikan dengan kemampuan ibu kader menjawab pertanyaan yang disampaikan tim pengabdi secara lisan dan kader juga mampu dalam pengisian stiker P4K tersebut. 
Berikut foto kegiatan pengabdian kepada masyarakat:

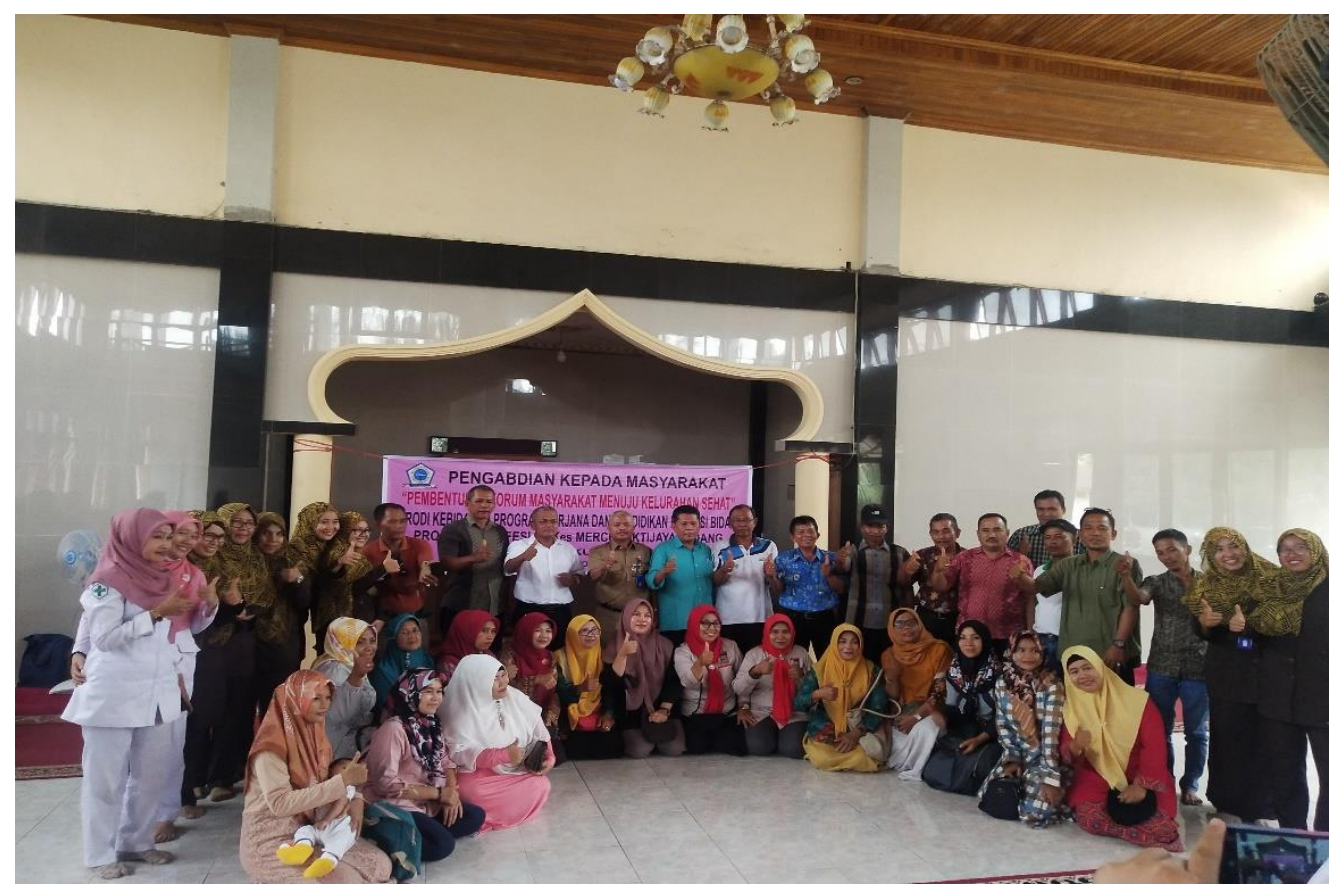

Gambar 1. Pembentukan forum peduli KIA bersama stakeholder dan kader di Kelurahan Kurao Pagang

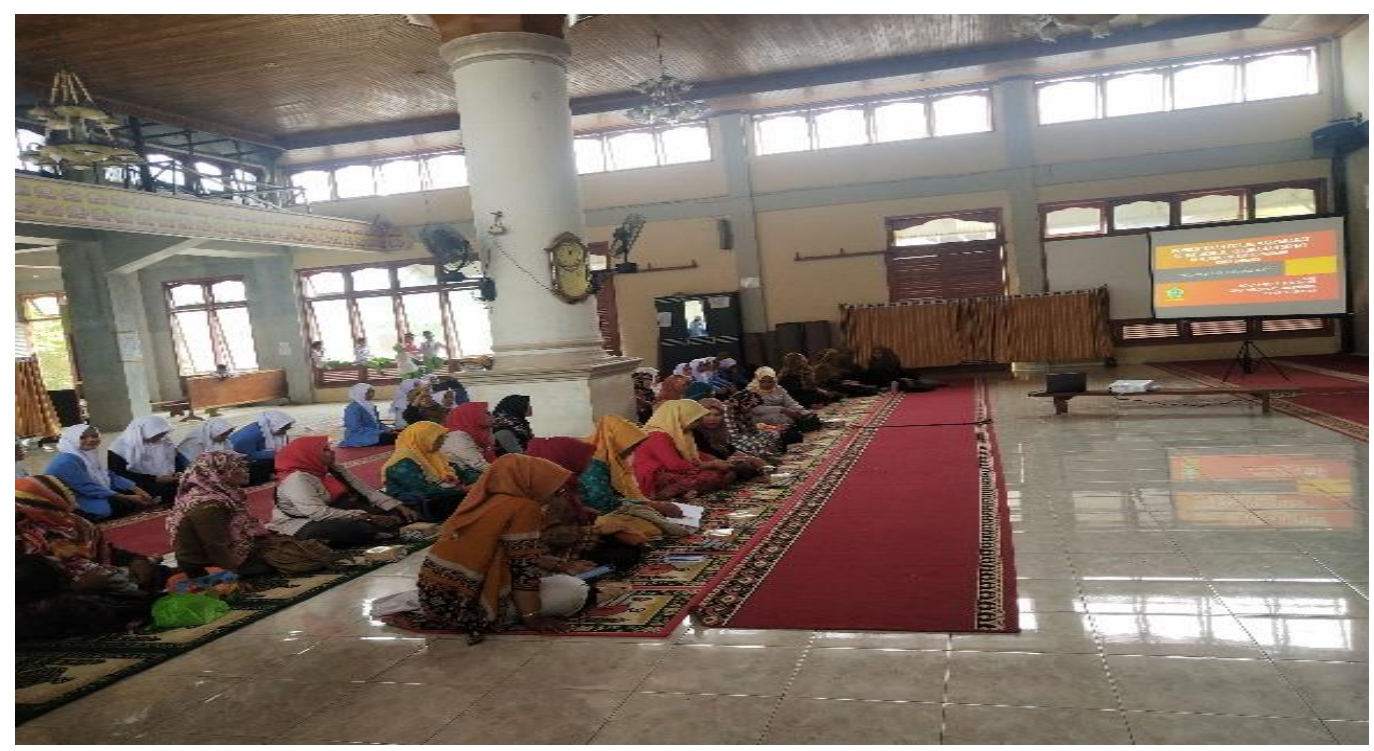

Gambar 2. Pemaparan materi tentang pentingnya pembentukan forum peduli KIA untuk pemantauan kesehatan ibu dan anak di wilayah kerja Kelurahan Kurao Pagang 


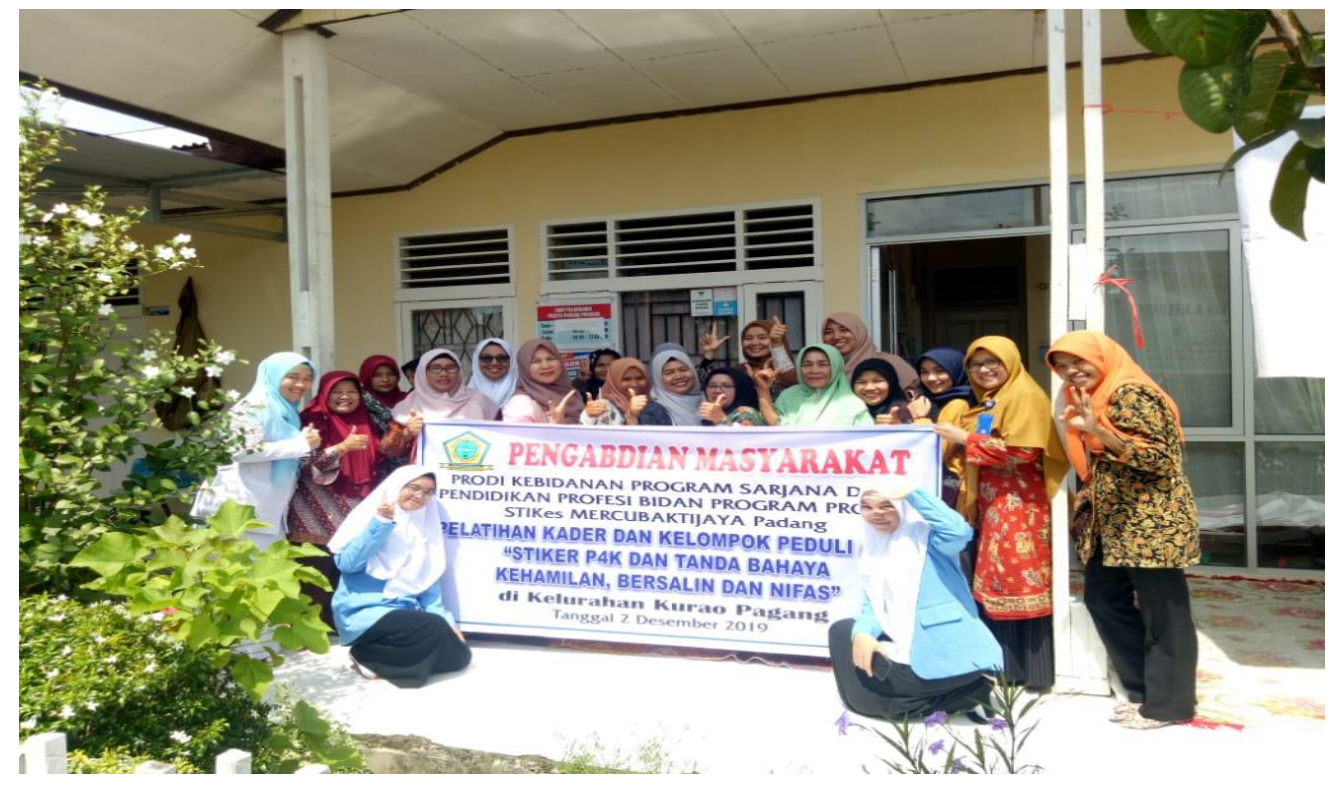

Gambar 3. Foto bersama kegiatan pelatihan kader dan forum peduli KIA tentang Stiker P4K, agenda rencana pemasangan stiker P4K bagi ibu hamil di wilayah kerja Kelurahan Kurao Pagang dan materi tentang tanda bahaya pada kehamilan, persalinan, dan nifas

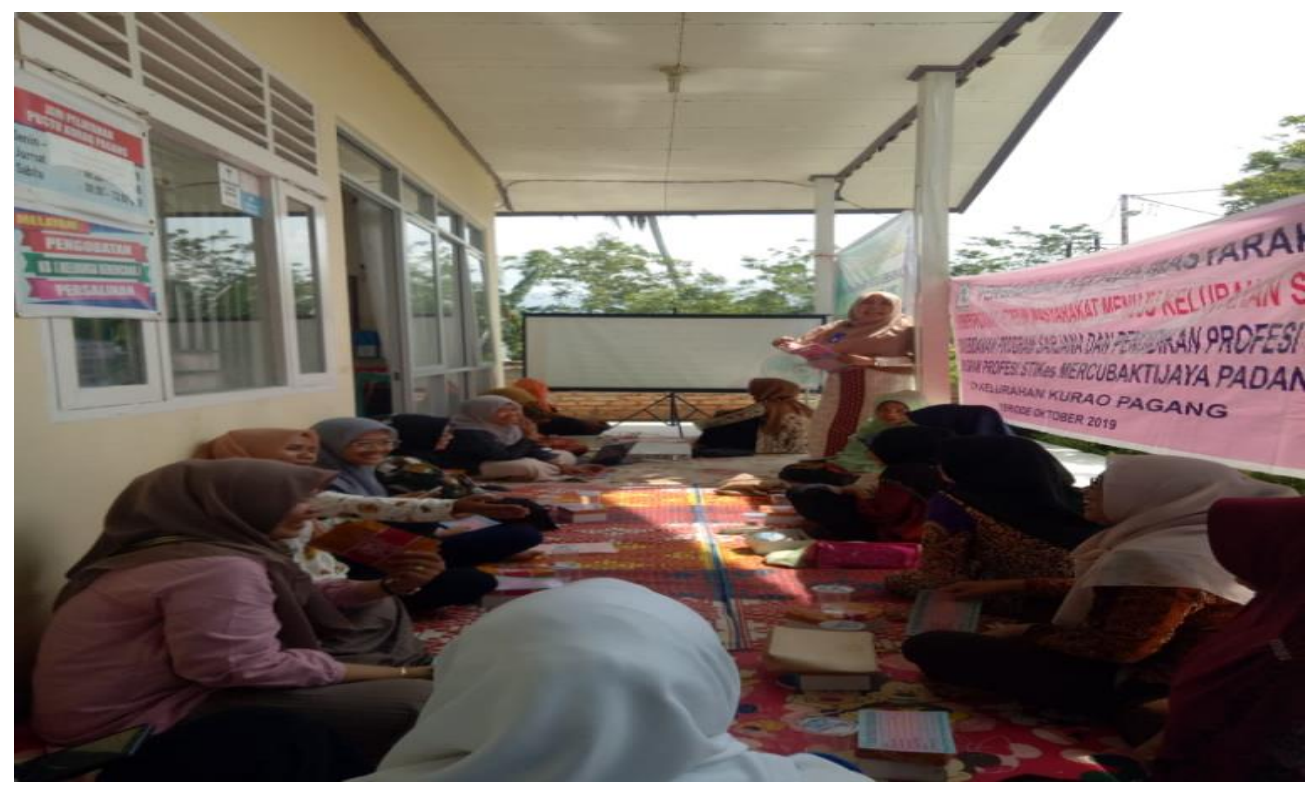

Gambar 4. Pemaparan materi tentang Stiker P4K dan tanda bahaya pada kehamilan, persalinan dan nifas kepada ibu kader posyandu dan ibu anggota forum peduli KIA di Kelurahan Kurao Pagang yang bertempat di Pustu Kurao Pagang

\section{HASIL DAN PEMBAHASAN}

Dari hasil pengabdian masyarakat yang telah dilakukan oleh tim pengabdi, maka dari yang sebelumnya tidak ada forum masyarakat peduli KIA, maka sudah terdapat forum peduli KIA ini. Selain itu, forum ini juga telah dibekali dengan pelatihan tentang tanda bahaya pada kehamilan, persalinan, dan nifas serta pelatihn tentang stiker P4K di Pustu Kurao Pagang, sehingga masyarakat khususnya kader dan kelompok forum ini sudah memahami tentang materi yang diberikan dengan baik sehingga dapat dilakukan secara berkelanjutan oleh masyarakat. 


\section{SIMPULAN}

Dari kegiatan pengabdian kepada masyarakat di kelurahan Kurao Pagang ini dapat disimpulkan bahwa terjalin koordinasi dengan baik antara tim pengabdi dengan masyarakat di kelurahan Kurao Pagang, sasaran pengabdi memberikan respon yang baik terhadap materi yang telah diberikan serta terdapat peningkatan kemampuan mitra kesehatan dalam menggunakan dan pengisian stiker P4K ketika tim pengabdi memberikan contoh kasus.

\section{SARAN}

Diharapkan kepada seluruh panitia yang sudah dibentuk pada forum peduli KIA ini untuk tetap melanjutkan pemantauan kesehatan ibu hamil di lingkungan tempat tinggal masing-masing dan tetap melakukan aksi pemasangan stiker P4K di masing-masing rumah ibu hamil. Selain itu, diharapkan dukungan yang penuh tetap diberikan oleh pihak Kelurahan maupun Puskesmas Pembantu di Kelurahan Kurao Pagang Kota Padang, sehingga program ini tetap berjalan dan dapat dikembangkan untuk program pengabdian kepada masyarakat dengan tema yang lainnya sesuai dengan kebutuhan dan permasalahan yang ada.

\section{UCAPAN TERIMA KASIH}

Tim pengabdi ingin mengucapkan terimakasih kepada Yayasan MERCUBAKTIJAYA Padang yang telah memberikan dukungan baik moril maupun materil sehingga kegiatan pengabdian kepada masyarakat ini dapat terwujud, Bapak Lurah Kelurahan Kurao Pagang Kota Padang beserta staf yang telah bersedia menerima tim pengabdi untuk dapat melaksanakan pengabdian kepada masyarakat di wilayah kerjanya serta memberikan dukungan penuh terhadap kegiatan ini, Puskesmas Nanggalo Kota Padang beserta jajaran yang telah bersedia menerima tim pengabdi untuk dapat melaksanakan pengabdian kepada masyarakat di wilayah kerjanya serta memberikan dukungan penuh terhadap kegiatan ini dan Seluruh pihak yang terlibat dalam pelaksanaan kegiatan pengabdian ini yang tidak bisa disebutkan satu persatu.

\section{DAFTAR PUSTAKA}

Dinas Kesehatan Kota Padang. (2017). Profil Kesehatan Kota Padang Tahun 2017. Dinas Kesehatan Kota Padang, (45), 1-176.

Kementerian Kesehatan Republik Indonesia. (2018). Profil Kesehatan Indonesia 2018 (Vol. 1227). https://doi.org/10.1002/qj

Muslihatun, W. N. (2009). Dokumentasi Kebidanan. Jakarta: Fitramaya.

Prasetyawati, A. E. (2012). Kesehatan Ibu dan Anak (KIA) : Dalam Millenium Development Goals $(M D G s)$. Yogyakarta: Nuha Medika.

Sarli, D., \& Ifayanti, T. (2018). FAKTOR-FAKTOR YANG BERPENGARUH TERHADAP PENERAPAN PROGRAM PERENCANAAN PERSALINAN DAN PENCEGAHAN KOMPLIKASI (P4K) DI KELURAHAN BALAI GADANG PADANG. Jurnal Ilmu Kesehatan (JIK), 2(April), 114-123.

Tengah, D. K. P. J. (2009). Laporan Tahunan Kesehatan Provinsi Jawa Tengah Tahun 2009. Semarang.

Yulianti, D. (2018). Peningkatan Kapasitas Sasaran Pelaksana Program Persiapan Persalinan dan Pencegahan Komplikasi (P4K) Dalam Pelaksanaan Strategi Untuk Mengurangi Angka Kematian Ibu (AKI) di Kecamatan Panjang Kota Bandar Lampung. Sakai Sambayan Jurnal Pengabdian Kepada Masyarakat, 2(1), 14. https://doi.org/10.23960/jss.v2i1.49 